\title{
Pengaruh Pupuk Organik terhadap Serapan Ca dan Mg serta Hasil Kacang Tanah pada Lahan Terdegradasi
}

\section{Effect of Organic Fertilizer on Uptake $\mathrm{Ca}$ and $\mathrm{Mg}$, and Yield of Groundnut on Degraded Land}

\author{
Anditya Syidiq Firmansyah ${ }^{1)}$, Sri Hartati ${ }^{2)}$, Hery Widijanto ${ }^{2)}$
}

\begin{abstract}
Degraded land is the land that has lost a lot of nutrients and soil organic matter. This research is aimed to determine the effect of the kinds of organic fertilizers to $\mathrm{Ca}$ and $\mathrm{Mg}$ uptake and yield of groundnuts on degraded land. This research was done using Completely Randomized Design (CRD) single factor and three replications for each treatment. The results showed that organic fertilizer influence to $\mathrm{Ca}$ and $\mathrm{Mg}$ uptake and the yield of groundnut on degraded lands. Eichonia crasspies manure increased $\mathrm{Ca}$ and $\mathrm{Mg}$ uptake of groundnut on degraded soil. Cow manure fertilizer increased $200 \%$ of their groundnut production as compared to without organic fertilizer.
\end{abstract}

Keywords : $\mathrm{Ca}$ and Mg uptake, degraded land, organic fertilizer, groundnuts

\section{PENDAHULUAN}

Tanah terdegradasi merupakan tanah yang telah kehilangan banyak unsur hara dan bahan organik tanah yang sebelumnya terdapat sangat banyak di dalamnya. Salah satu solusi yang dapat dilakukan adalah pemberian pupuk organik. Pupuk organik mempunyai kandungan unsur kimia makro yang sangat tinggi, selain itu pupuk organik tidak memberikan efek samping bagi tanah maupun tanaman (Firmansyah 2003).

Kacang tanah (Arachis hypogaea L.) adalah tanaman yang tumbuh di negara tropis dan subtropis. Daun kacang tanah memiliki tingkat ketebalan rendah (tipis) sehingga membentuk kanopi yang tembus cahaya dalam pertumbuhannya. Kacang tanah mampu menambat unsur $\mathrm{N}$ (Nitrogen) dengan bantuan bintil akarnya yang mengandung bakteri Rhizobium, sehingga mempunyai peran penting pada lahan terdegradasi. Kacang tanah juga sangat tahan pada kondisi kahat unsur $\mathrm{K}$ (Kalium). Tanah dengan kadar $\mathrm{K}$ terlalu tinggi justru kurang baik bagi kacang tanah, karena menghambat penyerapan unsur $\mathrm{Ca}$ dan Mg yang juga sangat diperlukan kacang tanah (Sumarno 1987).

Unsur $\mathrm{Ca}$ dan $\mathrm{Mg}$ merupakan unsur-unsur yang bersifat esensial bagi tumbuhan. Kekurangan kedua unsur tersebut dapat menyebabkan terhambatnya pertumbuhan tanaman dan berdampak negatif pula bagi hasil panen. Penelitian ini bertujuan untuk mengetahui pengaruh berbagai macam pupuk organik terhadap serapan $\mathrm{Ca}$ dan $\mathrm{Mg}$ serta pengaruhnya

\footnotetext{
1) Undergraduate Student of Study Program of Agrotechnology, Faculty of Agriculture University of Sebelas Maret (UNS) in Surakarta.

${ }^{2)}$ Lecturer of Study Program of Agrotechnology, Faculty of Agriculture University of Sebelas Maret (UNS) in Surakarta.
}

Contact Author: tatik_oc@yahoo.com terhadap hasil panen kacang tanah pada lahan terdegradasi (Rachman et al. 1999).

\section{METODE PENELITIAN}

Penelitian ini dilaksanakan pada bulan Mei 2012 sampai November 2012, berlokasi di Rumah Kaca Universitas Sebelas Maret Surakarta, Kec. Jumantono, Kab. Karanganyar. Sampel tanah untuk penelitian berasal dari Desa Sukosari, Kec. Jumantono, Kab. Karanganyar. Lokasi pengambilan sampel merupakan lahan bekas kegiatan produksi genteng dan batu bata. Alat yang digunakan adalah cangkul, karung, ember, $\mathrm{pH}$ meter, oven, neraca analitik, gelas ukur, dan alat tulis. Bahan yang digunakan adalah benih kacang tanah, pupuk kandang sapi, pupuk kandang ayam, pupuk kandang puyuh, pupuk kotoran kambing, bokashi, kompos jerami padi, kompos enceng gondok dan kompos titonia, pupuk dasar (Urea, SP-36, dan $\mathrm{KCl}$ ).

Penelitian ini menggunakan Rancangan Acak Lengkap (RAL) faktor tunggal dengan 9 perlakuan dan 3 ulangan. Faktor tunggal tersebut adalah berbagai pupuk organik [pupuk kandang sapi 5 ton ha ${ }^{1}$ (P1), pupuk kandang ayam 5 ton ha' ${ }^{-1}$ (P2), pupuk kandang puyuh 5 ton ha ${ }^{-1}$ (P3), pupuk kandang kambing 5 ton ha ${ }^{-1}(\mathrm{P} 4)$, pupuk bokashi 5 ton ha (P5), pupuk kompos jerami padi 5 ton ha ${ }^{-1}(\mathrm{P} 6)$, pupuk kompos enceng gondok 5 ton ha ${ }^{-1}$ (P7), dan pupuk kompos titonia 5 ton ha ${ }^{-1}$ (P8)] serta perlakuan tanpa pupuk organik sebagai kontrol (P0).

Pelaksanaan penelitian meliputi pengambilan tanah sebagai media tanam sebanyak $6 \mathrm{~kg}$ setiap ember, pencampuran tanah dengan pupuk organik diikuti proses inkubasi selama satu minggu. Penanaman benih dilakukan setelah masa inkubasi. Penanaman dilakukan dengan membuat lubang tanam kedalaman $3 \mathrm{~cm}$ sebanyak 2 benih/lubang tanam. Pemberian pupuk dasar berupa pupuk urea dosis 0,1 gram $\left(50 \mathrm{~kg} \mathrm{ha}^{-1}\right)$; SP36 dan $\mathrm{KCl}$ dosis 0,15 
gram (75 kg ha $\left.{ }^{-1}\right)$. Pemupukan dasar diberikan 2 kali yaitu pada saat tanam dan pada umur 4 minggu.

Pemeliharaan tanaman meliputi penyiraman yang dilakukan setiap hari hingga mencapai kondisi kapasitas lapangan. Penjarangan dilakukan setelah 1 minggu setelah tanam (MST), dimana hanya 1 tanaman sehat yang dibiarkan pada setiap lubang tanam. Pemanenan dilakukan pada saat 100 hari setelah tanam dengan kriteria batang mulai mengeras, daun menguning dan sebagian berguguran, polong sudah berisi penuh dan keras, dan warna polong coklat kehitaman.

Peubah yang diamati adalah $\mathrm{Ca}$ dan $\mathrm{Mg}$ jaringan (\%), serapan $\mathrm{Ca}$ dan $\mathrm{Mg}$ pada tanaman, tinggi tanaman $(\mathrm{cm})$, berat brangkasan segar dan kering (gram), berat polong basah dan kering (gram), dan jumlah polong per sampel (polong).

Data - data dari hasil pengamatan diuji secara statistik memakai software pengolah data Minitab 16.
Analisis data yang digunakan adalah uji $\mathrm{F}$ dengan taraf kepercayaan $95 \%$. Uji lanjut DMRT (Duncan Middle Range Test) digunakan untuk membandingkan antar rerata perlakuan. Untuk mengetahui keeratan hubungan dilakukan uji korelasi.

\section{HASIL DAN PEMBAHASAN}

\section{Karakteristik Tanah Awal}

Daerah tempat pengambilan sampel tergolong tanah alfisol. Kepekaan terhadap bahaya erosi pada tanah Alfisol sedang sampai besar. Tanah ini mempunyai sifat-sifat fisik yang sedang sampai baik, sedang sifat kimianya umumnya baik sehingga produktivitasnya adalah sedang sampai tinggi. Namun karena adanya kegiatan (seperti budidaya atau pemanfaatan genteng) maka tanah mengalami degradasi hara dan bahan organik.

Tabel 1. Hasil analisis tanah awal

\begin{tabular}{llll} 
No & Variabel & Satuan & Nilai (Pengharkatan) \\
\hline 1 & $\mathrm{pH} \mathrm{H} \mathrm{H}_{2} \mathrm{O}$ & - & 6,8 (Netral) \\
2 & $\mathrm{C} \mathrm{Organik}$ & $\%$ & 1,59 (Rendah) \\
3 & $\mathrm{KTK}$ & $\mathrm{Cmol} / \mathrm{kg}$ & 21,52 (Sedang) \\
4 & $\mathrm{~N} \mathrm{Total}$ & $\%$ & 0,17 (Sangat rendah) \\
5 & $\mathrm{C} / \mathrm{N} \mathrm{Ratio}$ & - & 9,35 (Sedang) \\
6 & $\mathrm{Ca} \mathrm{Tersedia}$ & $\mathrm{Cmol} / \mathrm{kg}$ & 2,84 (Rendah) \\
7 & Mg Tersedia & $\mathrm{Cmol} / \mathrm{kg}$ & 1,28 (Rendah) \\
\hline
\end{tabular}

Keterangan: Balittanah 2005.

Kandungan C-Organik, Ca, serta Mg tersedia rendah dan $\mathrm{N}$ total sangat rendah. Setelah proses inkubasi, terjadi peningkatan kandungan $\mathrm{Ca}$ tersedia, $\mathrm{Mg}$ tersedia, C/N ratio, C-Organik, dan KTK (Kapasitas Tukar Kation). Diasumsikan bahwa setelah inkubasi seminggu, unsur-unsur hara tiap pupuk organik sudah menyebar secara merata.

\section{Karakteristik Pupuk Organik}

Hasil pengharkatan karakteristik pupuk organik menunjukkan bahwa semua jenis pupuk organik yang digunakan memiliki kadar $\mathrm{C}$ Organik dan $\mathrm{N}$ total sangat tinggi. C/N Ratio merupakan indikator untuk menyatakan kematangan pupuk organik. Pupuk organik yang digunakan memiliki $\mathrm{C} / \mathrm{N}$ Ratio sedang hingga sangat tinggi, sehingga dapat dikatakan pupuk organik siap digunakan.

Tabel 2. Hasil analisis karakteristik pupuk organik

\begin{tabular}{|c|c|c|c|c|c|c|c|}
\hline Pupuk Organik & $\begin{array}{c}\text { C Organik } \\
(\%)\end{array}$ & $\begin{array}{c}\mathrm{N} \text { total } \\
(\%)\end{array}$ & $\begin{array}{c}\mathrm{C} / \mathrm{N} \\
\text { Ratio }\end{array}$ & $\begin{array}{c}\mathrm{pH} \\
\mathrm{H}_{2} \mathrm{O}\end{array}$ & $\begin{array}{c}\text { KTK } \\
\left(\mathrm{cmol}^{-1} \mathrm{~kg}^{-1}\right)\end{array}$ & $\begin{array}{l}\mathrm{Ca} \\
(\%)\end{array}$ & $\operatorname{Mg}(\%)$ \\
\hline Pukan Sapi & 40,36 & 1,541 & 26,19 & 7,82 & 16,00 & 2,9 & 0,7 \\
\hline Pukan Ayam & 23,93 & 1,376 & 17,39 & 7,40 & 22,00 & 2,9 & 0,6 \\
\hline Pukan Puyuh & 19,93 & 1,701 & 11,72 & 6,37 & 16,60 & 4,8 & 0,9 \\
\hline Pukan Kambing & 44,18 & 2,064 & 21,41 & 7,93 & 26,20 & 3,3 & 0,8 \\
\hline Bokhasi & 26,23 & 1,320 & 19,87 & 7,57 & 18,8 & 2,6 & 0,7 \\
\hline Jerami padi & 45,84 & 1,797 & 25,51 & 8,00 & 29,50 & 1,4 & 0,6 \\
\hline Enceng Gondok & 52,50 & 1,509 & 34,79 & 7,83 & 19,60 & 4,3 & 0,9 \\
\hline Kompos Titonia & 45,66 & 0,969 & 47,12 & 7,89 & 29,00 & 1,3 & 0,7 \\
\hline
\end{tabular}

Sumber: Hasil Analisis Laboratorium IImu Tanah FP UNS (2012).

Pengaruh Macam Bahan Organik terhadap Tanaman

\section{Berat Polong Kering}

Dari hasil penelitian ini berat polong kering tertinggi dicapai pada pupuk kandang sapi walaupun tidak berbeda nyata dibandingkan kompos jerami padi. Pupuk kandang sapi (P1) mampu meningkatkan berat polong kering sebanyak $20 \%$ dibandingkan dengan perlakuan tanpa pupuk organik (P0). 


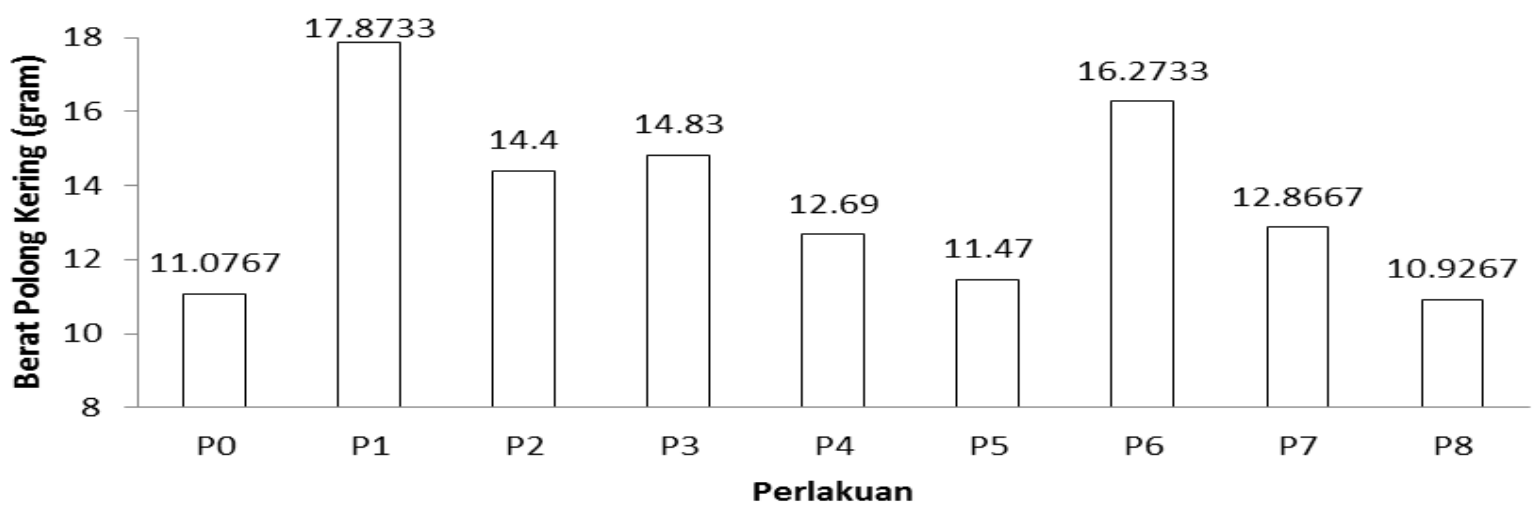

Gambar 1. Histogram pengaruh pupuk organik terhadap berat polong kering

\section{Berat Brangkasan Kering}

Berat brangkasan kering tanaman merupakan keseimbangan antara pengambilan $\mathrm{CO}_{2}$ dalam proses fotosintesis dan proses respirasi (Gardner et al. 1991). Ditambahkan pula oleh Sitompul dan Guritno (1995) bahwa produksi bahan kering tergantung dari penyerapan, penyinaran matahari, dan pengambilan $\mathrm{CO}_{2}$ dan air.

Analisis sidik ragam berat brangkasan kering kacang tanah menunjukkan bahwa perlakuan pupuk organik berpengaruh nyata terhadap berat brangkasan kering. Perlakuan pupuk kandang sapi (P1) mampu meningkatkan biomassa tanaman lebih tinggi daripada perlakuan tanpa pupuk organik (P0) yaitu $36 \%$. Hal tersebut sesuai dengan kemampuan setiap jenis pupuk dalam menyediakan hara esensial pada saat kacang tanah dalam fase vegetatif maksimum. Menurut Sulistyaningsih et al. (2005) laju pertumbuhan tanaman mengindikasikan peningkatan biomassa tanaman dalam komunitas persatuan luas tanah dalam satu satuan waktu.

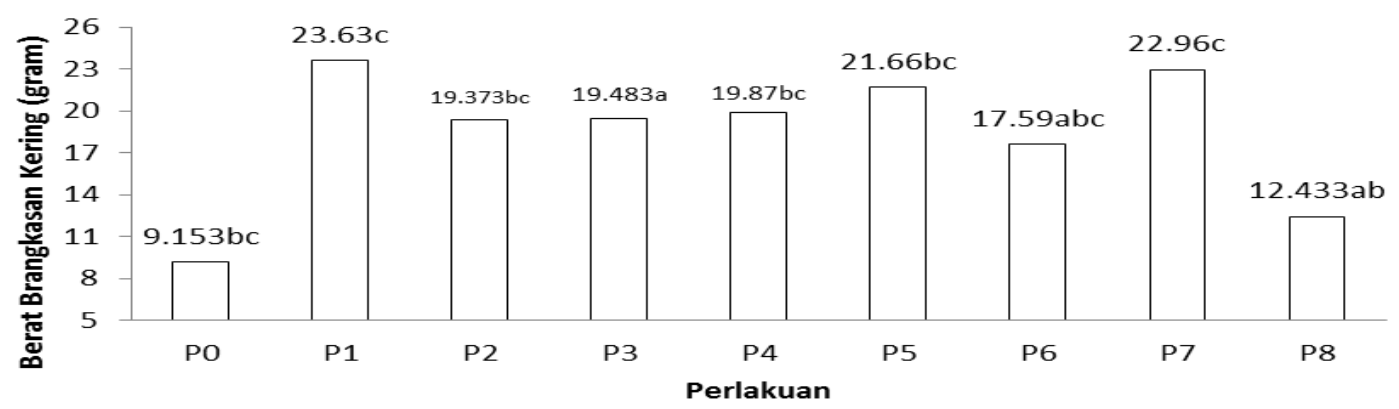

Gambar 2. Histogram pengaruh pupuk organik terhadap berat brangkasan kering

\section{Berat Biji}

Hasil analisis ragam menunjukkan bahwa perlakuan berbagai jenis pupuk organik yang digunakan berpengaruh nyata terhadap parameter berat biji kacang tanah. Perlakuan tanpa pupuk organik (P0) menghasilkan tinggi tanaman terendah dibandingkan jenis pupuk organik yang lain. Perlakuan pupuk kompos enceng gondok (P7) memiliki peningkatan berat biji paling tinggi dibanding dengan perlakuan lain sebanyak tiga kali lipat dari perlakuan tanpa pupuk organik (P0).

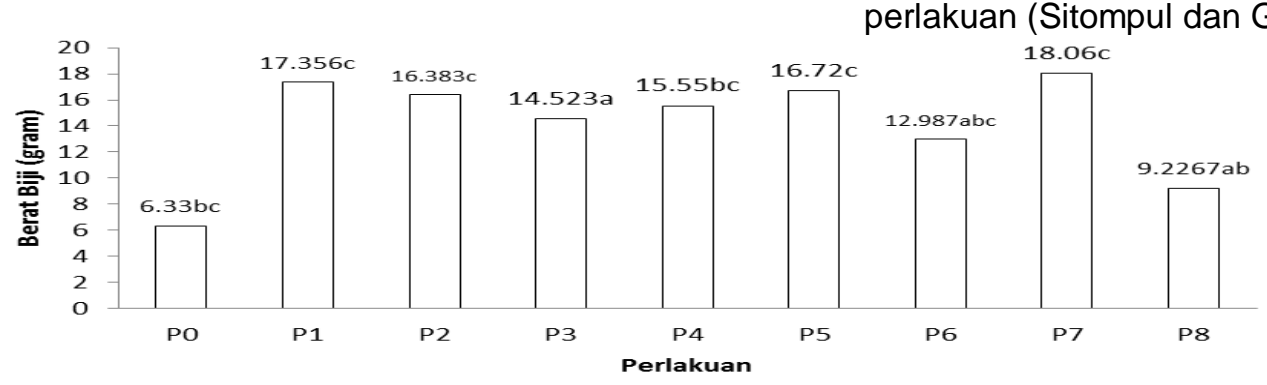

Gambar 3. Histogram pengaruh pupuk organik terhadap berat biji
Salah satu faktor yang menentukan kualitas bahan tanaman seperti biji adalah jumlah substrat seperti karbohidrat yang tersedia bagi metabolisme yang mendukung pertumbuhan awal tanaman. Hal ini menjadikan ukuran atau bobot bahan tanam (biji) sering digunakan sebagai tolak ukur untuk mendapatkan bahan tanam yang seragam. Tanah menyerap unsur $\mathrm{Ca}$ yang relatif sama dari pupuk organik yang diberikan. Hal ini berarti bahwa pembentukan biji sama efektifnya pada semua perlakuan (Sitompul dan Guritno, 1995). 


\section{Jumlah Biji}

Hasil analisis ragam menunjukkan bahwa perlakuan berbagai jenis pupuk organik yang digunakan berpengaruh nyata terhadap parameter jumlah biji kacang tanah. Perlakuan pupuk kandang sapi (P1) mampu meningkatkan jumlah biji kacang tanah $40 \%$ dibanding tanpa perlakuan (P0). Perlakuan ini memiliki kandungan unsur $\mathrm{Ca}$ yang optimal dalam metabolisme tanaman. Sesuai manfaatnya, $\mathrm{Ca}$ mampu membantu tanaman dalam pembentukan polong dan biji. Apabila kekurangan Ca maka akan terjadi penurunan jumlah polong yang terdapat pada perlakuan tanpa pupuk organik (P0) akibat dari lahan terdegradasi.

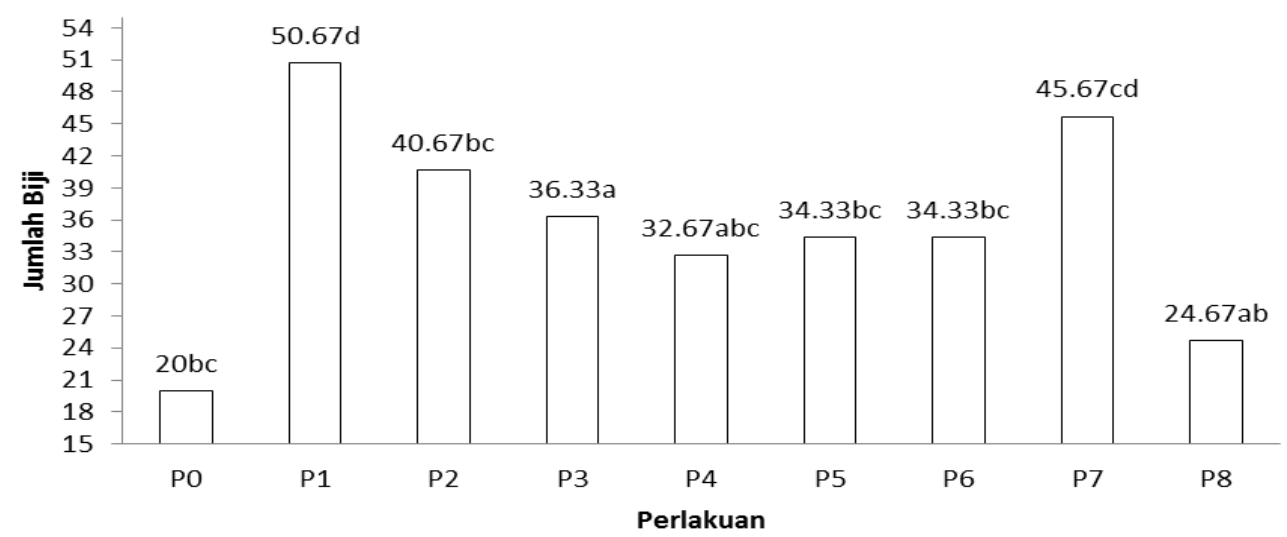

Gambar 4. Histogram pengaruh pupuk organik terhadap jumlah biji

\section{Serapan Ca}

Kandungan $\mathrm{Ca}$ dalam tanah tergantung dari bahan induk, derajat pelapukan, iklim dan tindakan pengapuran sebelumnya. Kalsium dalam tanah dipengaruhi oleh jenis tanah dan tingkat pelapukannya, misalnya konsentrasi $\mathrm{Ca}$ adalah $5 \%$ untuk Aridisol, 1\% untuk Alfisol dan 0,6\% untuk Oksisol (Barber, 1984). Kacang tanah membutuhkan Ca tinggi di zona perakaran, yang langsung dapat diserap akar dan ginofor untuk perkembangan polong secara normal. Tanaman legume mempunyai kandungan $\mathrm{Ca}$ 2-3 kali lebih banyak daripada rumput.

Berdasarkan analisis ragam menunjukkan bahwa pemberian berbagai pupuk organik berpengaruh nyata terhadap serapan Ca kacang tanah. Pemberian pupuk organik dengan hasil serapan $\mathrm{Ca}$ terendah terdapat pada perlakuan tanpa pupuk organik (PO) dan pupuk kotoran sapi (P1) yang menunjukan angka yang sama yaitu 0,07067 . Hasil tertinggi terdapat pada perlakuan pupuk kompos enceng gondok (P7), namun tidak terpaut jauh dengan perlakuan pupuk kotoran sapi (P1).

\section{Serapan Mg}

Magnesium merupakan unsur yang banyak didapatkan di dalam litosfer, dengan kandungan ratarata 2,1\%. Namun karena mineral-mineral Mg relatif mudah larut dan mudah mengalami pelapukan, maka rata-rata kandungan $\mathrm{Mg}$ dalam tanah hanya sekitar $0,5 \%$ saja. Tiga perempat dari $\mathrm{Mg}$ hilang selama berlangsungnya proses perkembangan tanah (Barber, 1984). Sumber $\mathrm{Mg}$ dalam tanah berasal dari pelapukan mineral primer yaitu biotit, serpentin, hornblende, dolomit dan olivin.

Analisis sidik ragam berat brangkasan kering kacang tanah dapat diketahui bahwa perlakuan pupuk organik berpengaruh nyata terhadap serapan $\mathrm{Mg}$. Perlakuan tanpa pupuk organik (P0) memiliki serapan $\mathrm{Mg}$ paling rendah. Perlakuan pupuk kotoran puyuh (P3) memiliki hasil tertinggi.

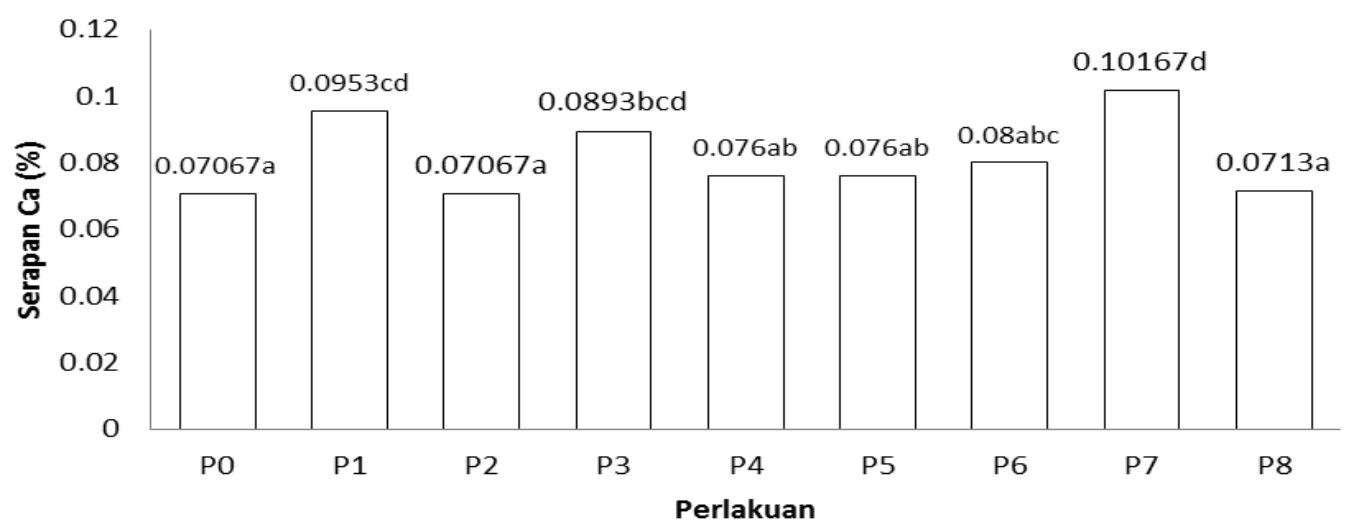

Gambar 5. Histogram pengaruh pupuk organik terhadap serapan $\mathrm{Ca}$ 


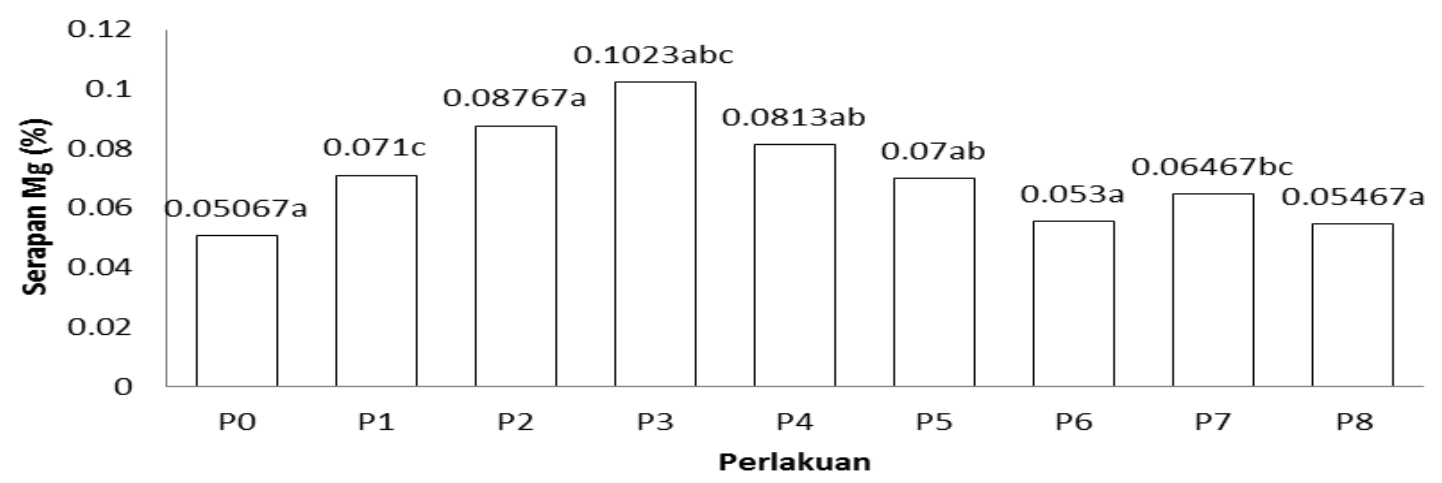

Gambar 6. Histogram pengaruh pupuk organik terhadap serapan $\mathrm{Mg}$

\section{KESIMPULAN DAN SARAN}

Kesimpulan dari penelitian ini diantaranya, sebagai berikut:

1. Macam pupuk organik yang berbeda mempengaruhi besar serapan Ca dan Mg kacang tanah pada lahan terdegradasi.

2. Penggunaan pupuk kompos enceng gondok dan pupuk kandang kotoran puyuh pada tanah terdegradasi mampu meningkatkan serapan $\mathrm{Ca}$ dan Mg kacang tanah.

3. Macam pupuk organik yang berbeda mempengaruhi berat dan jumlah biji kacang tanah pada lahan terdegradasi.

4. Pemberian pupuk kandang sapi meningkatkan jumlah biji yang dihasilkan dua kali lipat dibandingkan tanpa diberi pupuk.

\section{DAFTAR PUSTAKA}

Barber SA. 1984. Soil nutrient bioavailability, New York (NY): Jon Wiley \& Sons.

Firmansyah MA. 2003. Resiliensi tanah terdegradasi. Makalah pengantar falsafah sain. IPB.

Gardner FP, Pearce RB, Mitchell RL. 1991. Fisiologi tanaman budidaya (terj). Jakarta (ID): UI Press 428 hal.

Rachman HSK, Rais SA. 1999. Teknik produksi benih kacang tanah, Pusat Penelitian dan Pengembangan Pertanian, Bogor (ID): Badan Penelitian dan Pengembangan Pertanian.

Sitompul SM, Guritno B. 1995. Analisis pertumbuhan tanaman. Yogyakarta (ID): Gadjah Mada University Press. 412 hal.

Sulistyaningsih E, Kurniasih B, Kurniasih E. 2005. Pertumbuhan dan hasil caisin pada berbagai warna sungkup plastik. IImu Pertanian 12(1): 6576.

Sumarno. 1987. Teknik budidaya kacang tanah. Bandung (ID): Sinar Baru. 